\title{
Salt and ionic cocrystalline forms of amides: protonation of carbamazepine in aqueous media
}

Article

Accepted Version

Buist, A. R., Edgeley, D. S., Kabova, E. A., Kennedy, A. R., Hooper, D., Rollo, D. G., Shankland, K. and Spillman, M. J. (2015) Salt and ionic cocrystalline forms of amides:

protonation of carbamazepine in aqueous media. Crystal Growth \& Design, 15 (12). pp. 5955-5962. ISSN 1528-7483 doi: https://doi.org/10.1021/acs.cgd.5b01223 Available at https://centaur.reading.ac.uk/48596/

It is advisable to refer to the publisher's version if you intend to cite from the work. See Guidance on citing.

To link to this article DOI: http://dx.doi.org/10.1021/acs.cgd.5b01223

Publisher: American Chemical Society

All outputs in CentAUR are protected by Intellectual Property Rights law, including copyright law. Copyright and IPR is retained by the creators or other copyright holders. Terms and conditions for use of this material are defined in the End User Agreement. 


\section{CentAUR}

Central Archive at the University of Reading

Reading's research outputs online 


\title{
Salt and Ionic Cocrystalline Forms of Amides: Protonation of Carbamazepine in Aqueous Media.
}

\author{
Amanda R. Buist, ${ }^{\dagger}$ David S. Edgeley, ${ }^{\ddagger}$ Elena A. Kabova, ${ }^{\ddagger}$ Alan R. Kennedy, ${ }^{* \dagger}$ Debbie Hooper, ${ }^{\dagger}$ \\ David G. Rollo, Kenneth Shankland, ${ }^{\dagger}$ and Mark J. Spillman \\ ${ }^{\dagger}$ WestCHEM, Department of Pure and Applied Chemistry, University of Strathclyde, 295 Cathedral Street, Glasgow G1 1XL, \\ Scotland \\ ${ }^{\ddagger}$ School of Pharmacy, University of Reading, Reading RG6 6AD, England
}

Supporting Information

ABSTRACT: The products of reactions of the pharmaceutical amide carbamazepine (CBZ) with strong acids under aqueous conditions were investigated by both powder and single crystal $\mathrm{X}$-ray diffraction. Despite previous claims to the contrary, it was found that salt forms with $\mathrm{CBZ}$ protonated at the amide $\mathrm{O}$ atom could be isolated from reactions with both $\mathrm{HCl}$ and $\mathrm{HBr}$. These forms include the newly identified hydrate phase $[\mathrm{CBZ}(\mathrm{H})][\mathrm{Cl}] \cdot \mathrm{H}_{2} \mathrm{O}$. Reactions with other mineral acids ( $\mathrm{HI}$ and $\mathrm{HBF}_{4}$ ) gave ionic cocrystalline (ICC) forms (CBZ. [acridinium $]\left[\mathrm{I}_{3}\right] \cdot 2.5 \mathrm{I}_{2}$ and $\left.\mathrm{CBZ} \cdot\left[\mathrm{H}_{5} \mathrm{O}_{2}\right]_{0.25}\left[\mathrm{BF}_{4}\right]_{0.25} \cdot \mathrm{H}_{2} \mathrm{O}\right)$ as well as the salt form $\mathrm{CBZ} \cdot[\mathrm{CBZ}(\mathrm{H})]\left[\mathrm{BF}_{4}\right] \cdot 0.5 \mathrm{H}_{2} \mathrm{O}$. Reaction of $\mathrm{CBZ}$ with a series of sulfonic acids also gave salt forms, namely, $[\mathrm{CBZ}(\mathrm{H})]\left[\mathrm{O}_{3} \mathrm{SC}_{6} \mathrm{H}_{5}\right],[\mathrm{CBZ}(\mathrm{H})]\left[\mathrm{O}_{3} \mathrm{SC}_{6} \mathrm{H}_{4}(\mathrm{OH})\right]$.

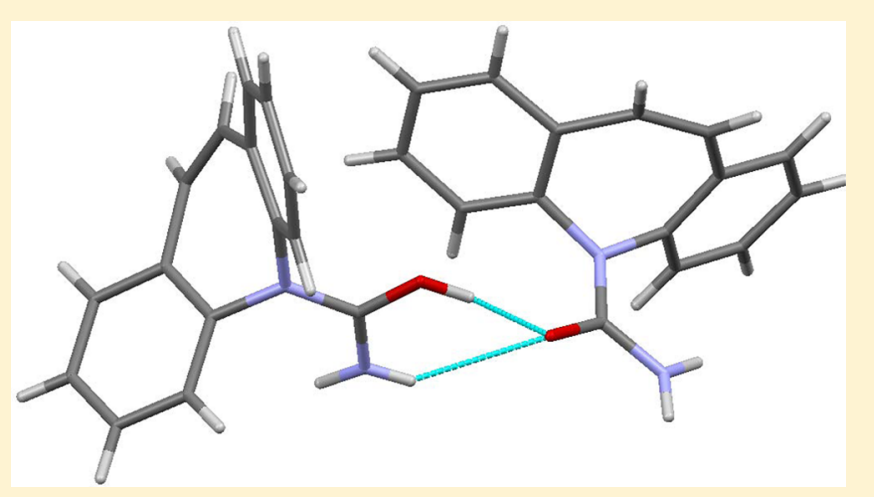
$0.5 \mathrm{H}_{2} \mathrm{O},[\mathrm{CBZ}(\mathrm{H})]_{2}\left[\mathrm{O}_{3} \mathrm{SCH}_{2} \mathrm{CH}_{2} \mathrm{SO}_{3}\right]$, and $[\mathrm{CBZ}(\mathrm{H})]\left[\mathrm{O}_{3} \mathrm{SC}_{6} \mathrm{H}_{3}(\mathrm{OH})(\mathrm{COOH})\right] \cdot \mathrm{H}_{2} \mathrm{O} . \mathrm{CBZ}$ and protonated $\mathrm{CBZ}(\mathrm{H})$ moieties can be differentiated in the solid state both by changes to molecular geometry and by differing packing preferences.

\section{INTRODUCTION}

Carbamazepine (CBZ) is an Active Pharmaceutical Ingredient (API) used in the treatment of epilepsy. As a relatively simple molecule with a nonpolar backbone and a single amide functionality, it has been widely studied by those interested in solid-form generation and the selection of APIs. Although extensive, this work has concentrated largely on CBZ polymorphs and on cocrystal or solvate forms where $\mathrm{CBZ}$ is accompanied in the solid by neutral coformers. ${ }^{1-11} \mathrm{~A}$ much smaller body of work exists on other classes of solid-state forms. Ionic cocrystalline (ICC) forms of $\mathrm{CBZ}$ with $\mathrm{NH}_{4}, \mathrm{OH}_{3}$, and $\mathrm{Na}$ cations have been structurally described, ${ }^{12-14}$ as, recently, have salt forms which feature protonation of $\mathrm{CBZ}$ at the amide $\mathrm{O}$ atom. ${ }^{14-16}$ These ICC and salt forms are interesting as they can and do exhibit different intermolecular bonding types and supramolecular synthons from those hydrogen bonding motifs that are well-described in, and common to, CBZ polymorphs and cocrystals. The ICC compounds do however seem to retain the nonpolar supramolecular constructs first described by Gelbrich and Hursthouse. ${ }^{17}$ This change in intermolecular bonding may in turn result in useful differences in material properties. $^{13-15,18,19}$

Salt forms of CBZ are also of interest simply because of the amide group acting as a Brønsted base. Many chemists assume that amide groups will not protonate under normally accessible conditions, and indeed CBZ itself has been used as a model "non-ionizable" API. ${ }^{20,21}$ However, although relatively rarely reported, salt forms of amides are accessible and isolatable in the solid as is shown by the elucidation of the crystal structures of salt forms of CBZ and of other amide species. ${ }^{22}$ Perumalla and Sun's original preparation of the salt $[\mathrm{CBZ}(\mathrm{H})][\mathrm{Cl}]$ utilized in situ generation of $\mathrm{HCl}$ in nonaqueous solvents. ${ }^{15}$ Similarly our own extension of this work to multiple phases of both CBZ hydrochloride and hydrobromide was based upon water free conditions and in situ generation of $\mathrm{HX}^{14}$ The original Perumalla and Sun work specified that this approach with nonaqueous conditions was necessary as $\mathrm{H}^{+}$generated in organic solution was more active than the solvated species (e.g., $\mathrm{H}_{3} \mathrm{O}^{+}$) that would be generated when using water as a solvent. Furthermore, with respect to aqueous acids, it was reported that "Attempts for synthesizing hydrochloride salt of CBZ, following the common salt formation approach, using even concentrated hydrochloride acid invariably led to the isolation of CBZ dihydrate". ${ }^{15}$ Later reports have led us to reinvestigate the use of aqueous acids. Notable prompts were Frampton and coworkers' isolation of $[\mathrm{CBZ}(\mathrm{H})]\left[\mathrm{MeSO}_{3}\right]$ from a reaction of CBZ with what was described as "neat" methanesulfonic acid $\left(\mathrm{p} K_{a}\right.$, approximately -2.6$)$ and, perhaps even more interestingly, their characterization of the product formed by reaction of CBZ with trifluoroethanoic acid ( $\mathrm{p} K_{\mathrm{a}}$, approximately -0.26$)$

Received: October 9, 2015

Revised: October 9, 2015 
Table 1. Selected Crystallographic and Refinement Parameters

\begin{tabular}{|c|c|c|c|c|}
\hline \multicolumn{2}{|c|}{ compound } & $\mathrm{CBZ} \cdot\left[\mathrm{C}_{13} \mathrm{H}_{10} \mathrm{~N}\right]\left[\mathrm{I}_{3}\right] \cdot 2.5 \mathrm{I}_{2}$ & $\mathrm{CBZ} \cdot[\mathrm{CBZ}(\mathrm{H})]\left[\mathrm{BF}_{4}\right] \cdot 0.5 \mathrm{H}_{2} \mathrm{O}$ & $\mathrm{CBZ} \cdot\left[\mathrm{H}_{5} \mathrm{O}_{2}\right]_{0.25}\left[\mathrm{BF}_{4}\right]_{0.25} \cdot \mathrm{H}_{2} \mathrm{O}$ \\
\hline formula & & $\mathrm{C}_{28} \mathrm{H}_{22} \mathrm{I}_{8} \mathrm{~N}_{3} \mathrm{O}$ & $\mathrm{C}_{30} \mathrm{H}_{26} \mathrm{BF}_{4} \mathrm{~N}_{4} \mathrm{O}_{2.5}$ & $\mathrm{C}_{15} \mathrm{H}_{15.25} \mathrm{~B}_{0.25} \mathrm{FN}_{2} \mathrm{O}_{2.5}$ \\
\hline fw & & 1431.69 & 569.36 & 285.24 \\
\hline cryst syst & & monoclinic & monoclinic & monoclinic \\
\hline space group & & $P 2_{1} / n$ & $C 2$ & $\mathrm{C} 2 / \mathrm{c}$ \\
\hline$\lambda, \AA$ & & 0.71073 & 0.71073 & 0.71073 \\
\hline$a, \AA$ & & $17.7346(16)$ & $26.8750(3)$ & $29.788(2)$ \\
\hline$b, \AA$ & & $9.2416(7)$ & $8.9636(7)$ & $5.1199(2)$ \\
\hline$c, \AA$ & & $22.5168(15)$ & $11.7505(13)$ & $21.1130(16)$ \\
\hline$\alpha, \operatorname{deg}$ & & 90 & 90 & 90 \\
\hline$\beta, \operatorname{deg}$ & & $99.498(7)$ & $104.459(12)$ & $120.804(10)$ \\
\hline$\gamma, \operatorname{deg}$ & & 90 & 90 & 90 \\
\hline vol, $\AA^{3}$ & & $3639.8(5)$ & $2741.0(4)$ & $2765.7(3)$ \\
\hline temp, $\mathrm{K}$ & & $123(2)$ & $123(2)$ & $123(2)$ \\
\hline$Z$ & & 4 & 4 & 8 \\
\hline reflens collcd & & 14505 & 4949 & 6940 \\
\hline $2 \theta \max , \operatorname{deg}$ & & 50.0 & 57.6 & 58.8 \\
\hline unique reflcns & & 6390 & 4121 & 3340 \\
\hline obsd reflens & & 3321 & 3053 & 2515 \\
\hline$R_{\mathrm{int}}$ & & 0.0982 & 0.0312 & 0.0234 \\
\hline goodness of fit & & 0.950 & 1.011 & 1.092 \\
\hline$R[I>2 s(I)], F$ & & 0.0595 & 0.0454 & 0.0479 \\
\hline$R_{w}, F^{2}$ & & 0.1298 & 0.1032 & 0.1115 \\
\hline $\max / \min$ electron $\mathrm{d}$ & $y$, e $\AA^{-3}$ & $1.461 /-1.216$ & $0.197 /-0.212$ & $0.219 /-0.255$ \\
\hline compound & {$[\mathrm{CBZ}(\mathrm{H})]\left[\mathrm{O}_{3} \mathrm{SC}_{6} \mathrm{H}_{5}\right]$} & {$[\mathrm{CBZ}(\mathrm{H})]_{2}\left[\mathrm{O}_{3} \mathrm{SCH}_{2} \mathrm{CH}_{2} \mathrm{SO}_{3}\right]$} & {$[\mathrm{CBZ}(\mathrm{H})]\left[\mathrm{O}_{3} \mathrm{SC}_{6} \mathrm{H}_{3}(\mathrm{OH})(\mathrm{COOH})\right] \cdot \mathrm{H}_{2} \mathrm{O}$} & {$[\mathrm{CBZ}(\mathrm{H})]\left[\mathrm{O}_{3} \mathrm{SC}_{6} \mathrm{H}_{4}(\mathrm{OH})\right] \cdot 0.5 \mathrm{H}_{2} \mathrm{O}$} \\
\hline formula & $\mathrm{C}_{21} \mathrm{H}_{18} \mathrm{~N}_{2} \mathrm{O}_{4} \mathrm{~S}$ & $\mathrm{C}_{32} \mathrm{H}_{30} \mathrm{~N}_{4} \mathrm{O}_{8} \mathrm{~S}_{2}$ & $\mathrm{C}_{22} \mathrm{H}_{20} \mathrm{~N}_{2} \mathrm{O}_{8} \mathrm{~S}$ & $\mathrm{C}_{21} \mathrm{H}_{19} \mathrm{~N}_{2} \mathrm{O}_{5.5} \mathrm{~S}$ \\
\hline fw & 394.43 & 662.72 & 472.46 & 419.44 \\
\hline cryst syst & monoclinic & triclinic & triclinic & monoclinic \\
\hline space group & $P 2_{1} / c$ & $P \overline{\overline{1}}$ & $P \overline{1}$ & $P n$ \\
\hline$\lambda, \AA$ & 0.71073 & 0.71073 & 0.71073 & 0.71073 \\
\hline$a, \AA$ & $10.5380(3)$ & $7.3746(7)$ & $7.1788(4)$ & $12.5378(9)$ \\
\hline$b, \AA$ & $15.4546(4)$ & $8.6949(10)$ & $12.3752(6)$ & $12.2352(7)$ \\
\hline$c, \AA$ & $12.0765(3)$ & $12.9832(11)$ & $13.2726(7)$ & $13.5144(11)$ \\
\hline$\alpha, \operatorname{deg}$ & 90 & $92.746(8)$ & $114.329(5)$ & 90 \\
\hline$\beta, \operatorname{deg}$ & $109.358(3)$ & $98.386(7)$ & $93.133(4)$ & $109.876(9)$ \\
\hline$\gamma, \operatorname{deg}$ & 90 & $104.180(9)$ & $97.161(4)$ & 90 \\
\hline vol, $\AA^{3}$ & $1855.59(9)$ & $795.46(14)$ & $1058.68(10)$ & $1949.6(3)$ \\
\hline temp, $\mathrm{K}$ & $123(2)$ & $123(2)$ & $123(2)$ & $123(2)$ \\
\hline$Z$ & 4 & 1 & 2 & 4 \\
\hline reflcns collcd & 8881 & 7642 & 9988 & 8477 \\
\hline $2 \theta$ max, deg & 59.1 & 55.9 & 58.0 & 54.0 \\
\hline unique reflcns & 4509 & 3436 & 5069 & 5421 \\
\hline obsd reflcns & 3461 & 2699 & 3801 & 4306 \\
\hline$R_{\text {int }}$ & 0.0234 & 0.0411 & 0.0323 & 0.0341 \\
\hline goodness of fit & 1.025 & 1.073 & 1.045 & 1.059 \\
\hline$R[I>2 s(I)], F$ & 0.0433 & 0.0616 & 0.0537 & 0.0494 \\
\hline$R_{\mathrm{w}}, F^{2}$ & 0.1001 & 0.1578 & 0.1403 & 0.1089 \\
\hline $\begin{array}{l}\max / \min \text { electron density, } \\
\text { e } \AA^{-3}\end{array}$ & $0.298 /-0.388$ & $0.770 /-0.360$ & $0.744 /-0.361$ & $0.533 /-0.439$ \\
\hline
\end{tabular}

as an intermediate or equilibrium species with a partial ionized, salt nature and a partial neutral, cocrystal nature. ${ }^{16}$ Thus, protonation of CBZ seems to be possible with species that have $\mathrm{p} K_{\mathrm{a}}$ values that are higher than would be expected for say concentrated aqueous $\mathrm{HCl}$. Finally, while our own work showed that adding drops of water to solid $[\mathrm{CBZ}(\mathrm{H})][\mathrm{Cl}]$ did indeed lead to a reversion to CBZ dihydrate, ${ }^{14}$ it also showed that slow addition of water to $[\mathrm{CBZ}(\mathrm{H})][\mathrm{X}](\mathrm{X}=\mathrm{Br}$ or $\mathrm{Cl})$ through exposure to air gave $[\mathrm{CBZ}(\mathrm{H})][\mathrm{Br}] \cdot \mathrm{H}_{2} \mathrm{O}$ and $[\mathrm{CBZ}]_{2}\left[\mathrm{H}_{3} \mathrm{O}\right][\mathrm{Cl}]$ thus showing that the presence of water was not incompatible with the existence of ionic phases of CBZ. ${ }^{14}$ Reported herein is a structural investigation of salt and
ICC forms of $\mathrm{CBZ}$ derived from reactions of $\mathrm{CBZ}$ with strong aqueous acids.

\section{EXPERIMENTAL SECTION}

Single crystal X-ray diffraction (SXD) measurements were performed at $123(2) \mathrm{K}$ using Oxford Diffraction instruments and $0.71073 \AA$ radiation. Structural refinements with all unique reflections and against $F^{2}$ to convergence were performed using programs from the SHELX suite. ${ }^{23}$ Hydrogen atoms bound to carbon were placed in idealized positions and refined in riding modes. Where possible, $\mathrm{H}$ atoms bound to nitrogen or oxygen were placed as found in difference Fourier syntheses and their positions were freely refined, but this was not possible for the $\mathrm{N}-\mathrm{H}$ atom on acridinium in structure CBZ. $\left[\mathrm{C}_{13} \mathrm{H}_{10} \mathrm{~N}\right]\left[\mathrm{I}_{3}\right] \cdot 2.5 \mathrm{I}_{2}$ for which a geometrically idealized riding model 
was required. Selected crystallographic and refinement parameters are given in Table 1. Full details have been deposited in cif format in the Supporting Information. See also CCDC 1419992-1419998.

Powder X-ray diffraction (PXRD) measurements were performed using a Bruker D8-Advance diffractometer equipped with a LynxEye detector and operating in transmission capillary mode using $\mathrm{Cu} \mathrm{Ka}$ incident radiation, $1.54056 \AA$ A. Samples were filled into $0.7 \mathrm{~mm}$ borosilicate glass capillaries and data collected using a step size of $0.017^{\circ} 2 \theta$. Data were analyzed using TOPAS. ${ }^{24}$ Diffraction patterns are given in the Supporting Information.

FTIR measurements were made on crushed, solid samples and with an $\mathrm{A}_{2}$ Technologies ATR instrument.

Reactions of CBZ with Aqueous $\mathrm{HCl}$. A $10 \mathrm{~mL}$ aliquot of concentrated hydrochloric acid (approximately 36\%) was added to a test tube containing $0.492 \mathrm{~g}(1.96 \mathrm{mmol})$ of CBZ. Despite stirring and heating for $30 \mathrm{~min}$, the $\mathrm{CBZ}$ did not appear to dissolve and there was no obvious, visible change. The solid was collected by filtration. PXRD analysis showed this to be a $89: 11$ mixture of $[\mathrm{CBZ}(\mathrm{H})][\mathrm{Cl}] \cdot \mathrm{H}_{2} \mathrm{O}$ : $[\mathrm{CBZ}(\mathrm{H})][\mathrm{Cl}]$ (form II). The filtrate was poured into a test tube and sealed with parafilm. Holes were pierced in the parafilm to aid evaporation. Slow evaporation over a period of 10 days gave a small number of colorless crystals. SXD and IR analyses showed that the previously known hydronium species $[\mathrm{CBZ}]_{2}\left[\mathrm{H}_{3} \mathrm{O}\right][\mathrm{Cl}]$ had formed. ${ }^{14}$

A $0.242 \mathrm{~g}$ (1.02 mmol) amount of CBZ was dissolved in $4 \mathrm{~mL}$ of ethanol. The solution was heated in a water bath until the CBZ had dissolved. Once the solution had cooled to room temperature, $2 \mathrm{~mL}$ of concentrated hydrochloric acid was slowly added. The test tube was then sealed with parafilm. Small holes were made in the parafilm to aid evaporation. Crystals formed over a period of a few days. SXD analysis showed that these were $[\mathrm{CBZ}]_{2}\left[\mathrm{H}_{3} \mathrm{O}\right][\mathrm{Cl}]$.

Reactions of CBZ with Aqueous $\mathrm{HBr}$. A $10 \mathrm{~mL}$ aliquot of concentrated hydrobromic acid (approximately 48\%) was added to a test tube containing $0.506 \mathrm{~g}(2.14 \mathrm{mmol})$ of CBZ. Despite stirring and heating for $30 \mathrm{~min}$, there was no obvious change and the CBZ did not appear to dissolve; instead the solid agglomerated at the top of the solution. The solid was collected by filtration. PXRD analysis showed this to be a 90:10 mixture of $[\mathrm{CBZ}(\mathrm{H})][\mathrm{Br}] \cdot \mathrm{H}_{2} \mathrm{O}:[\mathrm{CBZ}(\mathrm{H})][\mathrm{Br}]$ (form II).

A $0.204 \mathrm{~g}(0.86 \mathrm{mmol})$ amount of CBZ was dissolved in $4 \mathrm{~mL}$ of ethanol. The solution was heated in a water bath until the CBZ had dissolved. Once the solution had cooled to room temperature, $1 \mathrm{~mL}$ of concentrated hydrobromic acid was slowly added. The test tube was then sealed with parafilm. Small holes were made in the parafilm to aid evaporation. Crystals formed over a period of a few days. SXD analysis showed that these were $[\mathrm{CBZ}(\mathrm{H})][\mathrm{Br}] \cdot \mathrm{H}_{2} \mathrm{O}$.

Reaction of CBZ with Aqueous HI. A $1 \mathrm{~mL}$ aliquot of concentrated hydroiodic acid (approximately 55\%) was slowly added to a test tube containing $0.223 \mathrm{~g}(0.94 \mathrm{mmol})$ of CBZ. Despite gently heating and stirring for $30 \mathrm{~min}$, the bulk of the solid did not dissolve. The colorless solid was removed by filtration. On the basis of its IR spectrum this is not believed to be unreacted CBZ, but a positive identification was not possible. The remaining solution was allowed to slowly evaporate over several days depositing dark crystals. These were shown by SXD to be the acridinium containing ICC species CBZ. $\left[\mathrm{C}_{13} \mathrm{H}_{10} \mathrm{~N}\right]\left[\mathrm{I}_{3}\right] \cdot 2.5 \mathrm{I}_{2}$.

Reactions of CBZ with Aqueous $\mathrm{HBF}_{4}$. A $4 \mathrm{~mL}$ aliquot of concentrated hydrofluoroboric acid (approximately $40 \%$ ) was added to a test tube containing $0.228 \mathrm{~g}(0.97 \mathrm{mmol})$ of CBZ. Despite stirring and heating, there was no obvious change and the carbamazepine did not appear to dissolve. The colorless solid was collected by filtration but remains unidentified-see later text. No CBZ containing material was isolated from the filtrate.

A $0.239 \mathrm{~g}(1.01 \mathrm{mmol})$ amount of CBZ was dissolved in $4 \mathrm{~mL}$ of methanol. The solution was heated in a water bath until the CBZ had dissolved. Once the solution had cooled to room temperature, $1 \mathrm{~mL}$ of concentrated hydrofluoroboric acid was slowly added. The test tube was then sealed with parafilm. Small holes were made in the parafilm to aid evaporation. Examining the sample approximately 10 days later showed that two crystalline forms were present. Colorless crystals were shown by SXD analysis to be the CBZ hydronium species $\mathrm{CBZ}$. $\left[\mathrm{H}_{5} \mathrm{O}_{2}\right]_{0.25}\left[\mathrm{BF}_{4}\right]_{0.25} \cdot \mathrm{H}_{2} \mathrm{O}$, while orange crystals were $\mathrm{CBZ} \cdot[\mathrm{CBZ}(\mathrm{H})]$ $\left[\mathrm{BF}_{4}\right] \cdot 0.5 \mathrm{H}_{2} \mathrm{O}$.

Synthesis of $[\mathrm{CBZ}(\mathrm{H})]\left[\mathrm{O}_{3} \mathrm{SC}_{6} \mathrm{H}_{4}(\mathrm{OH})\right] \cdot 0.5 \mathrm{H}_{2} \mathrm{O}$. CBZ (0.202 g, $0.85 \mathrm{mmol}$ ) was added to a beaker containing $2.5 \mathrm{~mL}$ of aqueous 4 hydroxybenzosulfonic acid (65\%). The slurry was stirred and heated until the CBZ was fully dissolved. The clear solution was then poured into a small test tube wrapped in foil and covered with parafilm. Small holes were pierced in the film to allow evaporation to occur. After several days, crystals precipitated and were analyzed by SXD.

Synthesis of $[\mathrm{CBZ}(\mathrm{H})]\left[\mathrm{O}_{3} \mathrm{SC}_{6} \mathrm{H}_{5}\right]$. A $0.20 \mathrm{~g}(0.85 \mathrm{mmol})$ amount of $\mathrm{CBZ}$ was dissolved with heating in $3 \mathrm{~mL}$ of methanol. The solution was allowed to cool to room temperature, and then $1 \mathrm{~mL}$ of the aqueous solution formed by deliquescence of benzenesulfonic acid was slowly added. Slow evaporation produced crystals within 1 week. These were analyzed by SXD.

Synthesis of $[\mathrm{CBZ}(\mathrm{H})]\left[\mathrm{O}_{3} \mathrm{SC}_{6} \mathrm{H}_{3}(\mathrm{OH})(\mathrm{COOH})\right] \cdot \mathrm{H}_{2} \mathrm{O}$. A $0.20 \mathrm{~g}$ $(0.85 \mathrm{mmol})$ amount of $\mathrm{CBZ}$ was dissolved with heating in $4 \mathrm{~mL}$ of methanol. The solution was allowed to cool to room temperature, and then $1 \mathrm{~mL}$ of the aqueous solution formed by deliquescence of 5sulfosalicylic acid was added. Evaporation to dryness over 5 days gave a solid that was a mix of 5-sulfosalicylic acid and crystals of $[\mathrm{CBZ}(\mathrm{H})]\left[\mathrm{O}_{3} \mathrm{SC}_{6} \mathrm{H}_{3}(\mathrm{OH})(\mathrm{COOH})\right] \cdot \mathrm{H}_{2} \mathrm{O}$; these were analyzed by SXD.

Synthesis of $[\mathrm{CBZ}(\mathrm{H})]_{2}\left[\mathrm{O}_{3} \mathrm{SCH}_{2} \mathrm{CH}_{2} \mathrm{SO}_{3}\right]$. A $0.202 \mathrm{~g}(0.86 \mathrm{mmol})$ amount of $\mathrm{CBZ}$ and $0.269 \mathrm{~g}(1.42 \mathrm{mmol})$ of 1,2-ethanedisulfonic acid hydrate were dissolved in $4 \mathrm{~mL}$ of ethanol. The solution was heated in a water bath until both the CBZ and ethanedisulfonic acid had dissolved. The test tube was sealed with parafilm. Small holes were made in the parafilm to aid evaporation. Colorless crystals appeared within 5 days and were analyzed by SXD.

\section{RESULTS AND DISCUSSION}

Reactions of CBZ with Concentrated Strong Mineral Acids. It has previously been shown that in situ generation of $\mathrm{HX}(\mathrm{X}=\mathrm{Cl}$ or $\mathrm{Br})$ by adding acetyl halide to alcohol solutions of $\mathrm{CBZ}$ gives salt forms $[\mathrm{CBZ}(\mathrm{H})][\mathrm{X}]$ with the $\mathrm{CBZ}(\mathrm{H})$ cation formed by protonation at the amide $\mathrm{O}$ atom of $\mathrm{CBZ}{ }^{14,15}$ Both the chloride containing and the bromide containing species were isolated as three solid phases. In each case the initially produced anhydrous salts, designated as form I, transform with time into new polymorphs. These form II polymorphs of the hydrochloride and hydrobromide species are mutually isostructural. Prolonged exposure to air results in hydration of both form II species. In the case of bromide this gives simply a hydrated phase, $[\mathrm{CBZ}(\mathrm{H})][\mathrm{Br}] \cdot \mathrm{H}_{2} \mathrm{O}$, but for the chloride there is a partial loss of $\mathrm{HCl}$ and a proton transfer from $\mathrm{CBZ}(\mathrm{H})$ to water to give the solid-state hydronium species $[\mathrm{CBZ}]_{2}\left[\mathrm{H}_{3} \mathrm{O}\right]$ $[\mathrm{Cl}] .{ }^{14}$ As it contains only neutral $\mathrm{CBZ}$, this last phase can best be described as an ICC phase rather than as a true salt form of CBZ. $^{13}$

Our initial attempts to form salt forms of CBZ using aqueous acids simply involved adding concentrated strong acids $(\mathrm{HCl}$, $\mathrm{HBr}, \mathrm{HI}$, and $\mathrm{HBF}_{4}$ ) to solid CBZ. Despite heating there was no apparent dissolution of the CBZ nor was there any other visually apparent change. It is possible that the lack of apparent dissolution and of any other visual change contributed to the previous assertion that no reaction takes place under such conditions. ${ }^{15}$ However, on recovering the solid powders from the acidic slurries, investigation by IR spectroscopy showed that the recovered materials were neither CBZ nor its dihydrate. For detail of the differences between $\mathrm{CBZ}$ and $[\mathrm{CBZ}(\mathrm{H})][\mathrm{X}], \mathrm{X}=$ $\mathrm{Cl}$ or $\mathrm{Br}$, spectra see ref 14 .

The solid recovered from the reaction of $\mathrm{CBZ}$ with concentrated aqueous $\mathrm{HCl}$ was found by PXRD to be a mixed phase. Once a contribution from form II of $[\mathrm{CBZ}(\mathrm{H})]$ - 
[Cl] was identified, the remaining peaks were indexed to a unit cell $(a=5.0341(3) \AA, b=11.1488(8) \AA, c=25.7824(15) \AA, \beta$ $=91.251(3)^{\circ}, V=1446.68(15) \AA^{3}, P 2_{1} / n$, and $\left.T=293 \mathrm{~K}\right)$ that closely matched that of the known species $[\mathrm{CBZ}(\mathrm{H})][\mathrm{Br}]$. $\mathrm{H}_{2} \mathrm{O}$, ${ }^{14}$ suggesting that a new hydrated $\mathrm{CBZ}$ hydrochloride phase isostructural to that of the hydrobromide has been identified; see Figure 1. A two-phase Pawley refinement, based

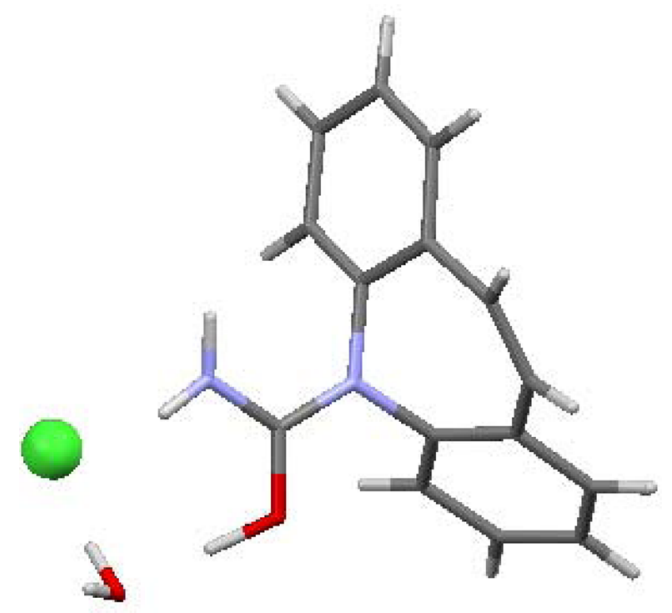

Figure 1. Structure of $[\mathrm{CBZ}(\mathrm{H})][\mathrm{Cl}] \cdot \mathrm{H}_{2} \mathrm{O}$ as determined by PXRD. Protonation of $\mathrm{CBZ}$ is at the $\mathrm{O}$ atom of the amide group, and this group donates a short $\mathrm{O}-\mathrm{H} \cdots \mathrm{O}$ hydrogen bond to the water molecule $(\mathrm{O} \cdots \mathrm{O}, 2.520 \AA)$.

on this cell and that of form II of $[\mathrm{CBZ}(\mathrm{H})][\mathrm{Cl}]$, gave an excellent fit $\left(R_{\mathrm{wp}}=3.26,6-70^{\circ} 2 \theta\right)$ to the PXRD data. A twophase rigid-body Rietveld refinement $\left(R_{\mathrm{wp}}=5.25,6-70^{\circ} 2 \theta\right)$ showed the mixture composition to be $11 \%$ form II of $[\mathrm{CBZ}(\mathrm{H})][\mathrm{Cl}]$ and $89 \%$ of the novel hydrated CBZ hydrochloride. See the Supporting Information for refinement details.

A third ionic form containing CBZ was also isolated from the same reaction. Evaporation of the remaining aqueous acid to dryness gave a small number of crystals suitable for SXD. These were shown to be the known hydronium species, $[\mathrm{CBZ}]_{2}\left[\mathrm{H}_{3} \mathrm{O}\right][\mathrm{Cl}] .^{14}$ Low aqueous solubility of $\mathrm{CBZ}$ and its ionic forms is an experimental hindrance here. In an attempt to form larger crystals of the new hydrochloride hydrate phase for SXD study, an ethanol solution of CBZ was prepared and concentrated aqueous $\mathrm{HCl}$ added to this. This approach did give large crystals, but these were not the desired hydrate phase. Instead they were also identified as the hydronium species, $[\mathrm{CBZ}]_{2}\left[\mathrm{H}_{3} \mathrm{O}\right][\mathrm{Cl}] .^{14}$

Reaction of $\mathrm{CBZ}$ with concentrated aqueous $\mathrm{HBr}$ followed a pattern similar to the equivalent reaction with $\mathrm{HCl}$. The bulk of the CBZ appeared not to dissolve, but analysis of the recovered powder by PXRD (following a similar Pawley and Rietveldbased approach to that already detailed for the $\mathrm{HCl}$ product; data range, $5-65^{\circ} 2 \theta$ ) showed it to be composed of $90 \%$ $[\mathrm{CBZ}(\mathrm{H})][\mathrm{Br}] \cdot \mathrm{H}_{2} \mathrm{O}$ and $10 \%$ form II $[\mathrm{CBZ}(\mathrm{H})][\mathrm{Br}]$; see Supporting Information. Reaction of an ethanol solution of CBZ with concentrated aqueous $\mathrm{HBr}$ yielded crystals only of the hydrated salt. To summarize, despite previous descriptions, reaction with concentrated $\mathrm{HCl}$ does not simply return $\mathrm{CBZ}$ dihydrate. Instead a number of ionic species were produced. From purely aqueous media the main product was found to be a new phase, namely, the hydrate of CBZ hydrochloride, but both form II of anhydrous CBZ hydrochloride and the hydronium chloride form of $\mathrm{CBZ}$ were also present. Reaction of $\mathrm{CBZ}$ with concentrated aqueous $\mathrm{HBr}$ gave mostly the hydrated salt form, with a small amount of anhydrous salt material also present.

Reactions of CBZ with $\mathrm{HI}$ proceeded differently. The colored product formed on treating solid CBZ with concentrated aqueous $\mathrm{HI}$ was found to contain $\mathrm{CBZ}$. $\left[\mathrm{C}_{13} \mathrm{H}_{10} \mathrm{~N}\right]\left[\mathrm{I}_{3}\right] \cdot 2.5 \mathrm{I}_{2}$; see Figure 2. Here an ICC species has

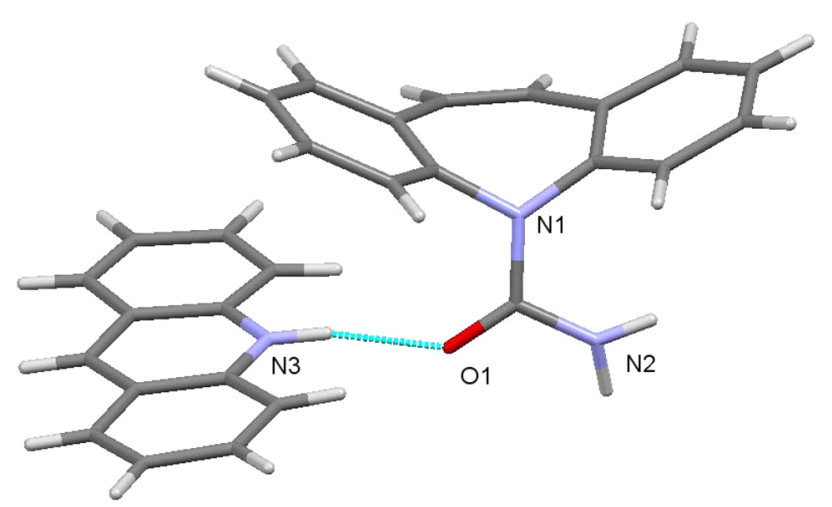

Figure 2. Hydrogen bonded $\mathrm{CBZ} /$ acridinium pair from the crystal structure of $\mathrm{CBZ} \cdot\left[\mathrm{C}_{13} \mathrm{H}_{10} \mathrm{~N}\right]\left[\mathrm{I}_{3}\right] \cdot 2.5 \mathrm{I}_{2}$.

been formed with the final product containing neutral CBZ molecules, cationic acridinium, and a polyiodide array that can be best rationalized as one $\mathrm{I}_{3}$ anion and 2.5 neutral $\mathrm{I}_{2}$ molecules per CBZ. The structures of the somewhat related ICC species $\mathrm{CBZ} \cdot\left[\mathrm{NH}_{4}\right][\mathrm{X}], \mathrm{X}=\mathrm{Cl}$ and $\mathrm{Br}$, have previously been described. ${ }^{12,13}$ Acridine may seem like a surprising inclusion, but it is a well-known metabolite of CBZ and is produced by decomposition of CBZ under a variety of chemical and biological conditions. ${ }^{25-27}$ It has also previously been trapped during the crystallization of $\mathrm{CBZ}$ in the presence of $\mathrm{NaI}$ and $\mathrm{HBr}$ as the ICC complex $\left[\mathrm{Na}(\mathrm{CBZ})_{5}\right]\left[\mathrm{C}_{13} \mathrm{H}_{10} \mathrm{~N}\right]\left[\mathrm{IBr}_{2}\right]_{2}{ }^{13}$ The fibrous crystals of $\mathrm{CBZ} \cdot\left[\mathrm{C}_{13} \mathrm{H}_{10} \mathrm{~N}\right]\left[\mathrm{I}_{3}\right] \cdot 2.5 \mathrm{I}_{2}$ diffracted weakly, so the resulting crystal structure has a relatively low resolution especially with respect to the light atom organic components. It can be seen though that the acridinium cation forms a single $\mathrm{N}-\mathrm{H} \cdots \mathrm{O}$ hydrogen bond with the $\mathrm{O}$ atom of the CBZ amide group. Notably there are no hydrogen bonds involving either the cation or CBZ and any of the I centers; indeed the I centers form only I...I short contacts. An ICC structure with no apparent short/strong cation to anion attractive interaction is unusual. The packing structure of $\mathrm{CBZ} \cdot\left[\mathrm{C}_{13} \mathrm{H}_{10} \mathrm{~N}\right]\left[\mathrm{I}_{3}\right] \cdot 2.5 \mathrm{I}_{2}$ is shown in Figure 3. It is obvious from this figure that this ICC form is very different from other phases of CBZ. The normal organic to organic interactions that dominate the packing and hence the physical properties of most known forms of CBZ cannot adequately define the packing of this species. Note the layering motif with most of the $\mathrm{I}_{3}$ and $\mathrm{I}_{2}$ species occupying layers parallel to the $a b$ plane but with a single crystallographically independent $\mathrm{I}_{2}$ molecule lying within the otherwise wholly organic $a b$ layer.

The final concentrated mineral acid reacted with $\mathrm{CBZ}$ was $\mathrm{HBF}_{4}$. There were similarities to the $\mathrm{HCl}$ and $\mathrm{HBr}$ reactions in that treating solid $\mathrm{CBZ}$ with the concentrated acid did not give any apparent dissolution of the CBZ. Analyzing the powder recovered from the acid by IR spectroscopy indicated that it contained both $\mathrm{CBZ}$ and $\mathrm{BF}_{4}$ anions; however, PXRD of this material was inconclusive as we were unable to index the 


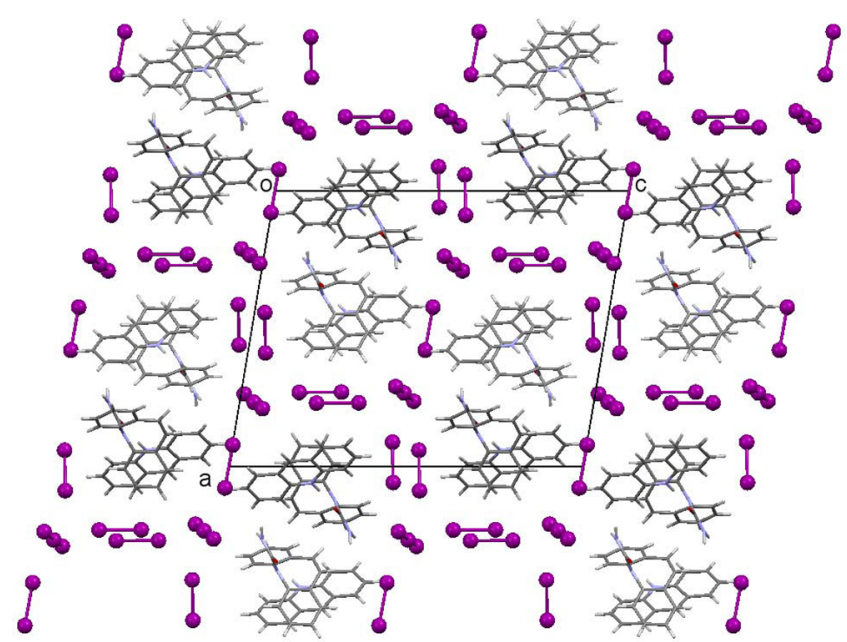

Figure 3. Packed structure of the ICC species CBZ $\left[\mathrm{C}_{13} \mathrm{H}_{10} \mathrm{~N}\right]\left[\mathrm{I}_{3}\right]$. $2.5 \mathrm{I}_{2}$ with view down the $b$ axis.

pattern. It is likely to consist of a mixture of phases. In an attempt to grow crystals suitable for SXD analysis, concentrated $\mathrm{HBF}_{4}$ was added to a methanol solution of CBZ. Crystals did indeed grow, but there were obviously two products, one colorless and one light orange. The colorless crystals were not a true salt form of $\mathrm{CBZ}$ as they contained a hydronium cation rather than $\mathrm{CBZ}(\mathrm{H})$ and analyzed as the ICC species CBZ. $\left[\mathrm{H}_{5} \mathrm{O}_{2}\right]_{0.25}\left[\mathrm{BF}_{4}\right]_{0.25} \cdot \mathrm{H}_{2} \mathrm{O}$. In this structure there are four neutral $\mathrm{CBZ}$ molecules per $\left[\mathrm{H}_{5} \mathrm{O}_{2}\right]\left[\mathrm{BF}_{4}\right]$ ion pair and the ions are disordered about the crystallographic 2 -fold axis. The water molecules are also disordered. Despite the requirement to model partially occupied $\mathrm{H}$ atoms to identify the cationic groups, the characterization of the chemical identity of this species is certain. Supporting this is the previous identification of hydronium ion ICC species found on reaction of aqueous $\mathrm{HCl}$ with $\mathrm{CBZ}$ (above) and after reaction of in situ generated $\mathrm{HCl}$ with the CBZ congener cytenamide. ${ }^{14}$ Furthermore, the presence of (partial) $\mathrm{BF}_{4}$ is certain from both IR and SXD evidence, and charge balance thus requires a cation to be present in the structure. Both molecular and intramolecular structural features also support a firm identification as a hydronium species. In more detail, protonation of CBZ has been shown to cause characteristic lengthening of the amide $\mathrm{C}=\mathrm{O}$ bond accompanied by shortening of the $\mathrm{C}-\mathrm{N}$ bonds. ${ }^{14,16}$ Such bond length effects are absent here; see Table 2 for details. Finally, the supramolecular structures of neutral CBZ containing forms have received much attention, and they are known to commonly contain either homodimeric hydrogen bonded pairs, or polymeric hydrogen bonded chains of CBZ molecules, or heterodimer hydrogen bonded pairs formed between CBZ and a suitable coformer such as a carboxylic acid. ${ }^{4,7,17}$ In the structure of $\mathrm{CBZ}$. $\left[\mathrm{H}_{5} \mathrm{O}_{2}\right]_{0.25}\left[\mathrm{BF}_{4}\right]_{0.25} \cdot \mathrm{H}_{2} \mathrm{O}$ the solvated $\mathrm{R} 2,2(8)$ homodimer motif is present (Figure 4). This motif is common in other neutral CBZ containing species (including hydronium ICC species) but absent from structures that contain the $\mathrm{CBZ}(\mathrm{H})$ cation. $^{14}$

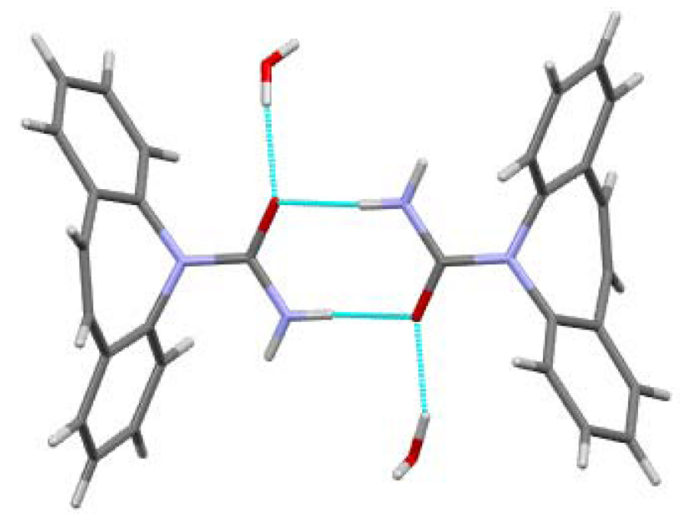

Figure 4. Hydrogen bonded solvated $\mathrm{CBZ}$ homodimer from the structure of the hydronium ion species CBZ $\cdot\left[\mathrm{H}_{5} \mathrm{O}_{2}\right]_{0.25}\left[\mathrm{BF}_{4}\right]_{0.25} \cdot \mathrm{H}_{2} \mathrm{O}$. This supramolecular motif is common in other structures that also contain neutral CBZ.

The orange crystals isolated from the same reaction of CBZ and $\mathrm{HBF}_{4}$ do contain protonated $\mathrm{CBZ}$ ions, but they also contain neutral CBZ molecules and have formula CBZ. $[\mathrm{CBZ}(\mathrm{H})]\left[\mathrm{BF}_{4}\right] \cdot 0.5 \mathrm{H}_{2} \mathrm{O}$. This is the first structurally characterized species known to contain crystallographically discrete $\mathrm{CBZ}$ and $\mathrm{CBZ}(\mathrm{H})$ fragments. Note though that the $\mathrm{CF}_{3} \mathrm{COO}$ and hydrobromide hydrate salts of $\mathrm{CBZ}$ have been described as species that feature dynamic equilibria that imply the existence of $\mathrm{CBZ}$ and $\mathrm{CBZ}(\mathrm{H})$ on the same (disordered) sites. ${ }^{14,16}$ The $\mathrm{C}=\mathrm{O}$ and $\mathrm{C}-\mathrm{N}$ bond lengths of the $\mathrm{CBZ}$ and $\mathrm{CBZ}(\mathrm{H})$ fragments are clearly different from each other (Table 2) and are in good agreement with other values for neutral and cationic CBZ species. This differentiation comes despite the $\mathrm{O}-\mathrm{H}$ proton being situated between the $\mathrm{O}$ atoms of $\mathrm{CBZ}$ and $\mathrm{CBZ}(\mathrm{H})$; see Figure 5. Despite this arrangement and the short

Table 2. Amide Group Bond Lengths for Protonated and Neutral CBZ

$\begin{array}{llll} & \mathrm{C}=\mathrm{O}(\AA) & \mathrm{C}-\mathrm{NH}_{2}(\AA) & \mathrm{C}-\mathrm{N}_{\text {ring }}(\AA) \\ \text { neutral CBZ } & & 1.373 \\ \text { cationic CBZ(H) } & 1.242 & 1.342 & 1.323-1.338 \\ \mathrm{CBZ} \cdot\left[\mathrm{H}_{5} \mathrm{O}_{2}\right]_{0.25}\left[\mathrm{BF}_{4}\right]_{0.25} \cdot \mathrm{H}_{2} \mathrm{O} & 1.299-1.312 & 1.304-1.326 & 1.369(2) \\ \mathrm{CBZ} \cdot[\mathrm{CBZ}(\mathrm{H})]\left[\mathrm{BF}_{4}\right] \cdot 0.5 \mathrm{H}_{2} \mathrm{O} & 1.2471(18) & 1.340(2) & 1.360(4) \\ \mathrm{CBZ} \cdot[\mathrm{CBZ}(\mathrm{H})]\left[\mathrm{BF}_{4}\right] \cdot 0.5 \mathrm{H}_{2} \mathrm{O} & 1.249(4) & 1.364(4) & 1.348(4) \\ {[\mathrm{CBZ}(\mathrm{H})]\left[\mathrm{O}_{3} \mathrm{SC}_{6} \mathrm{H}_{5}\right]} & 1.295(4) & 1.313(4) & 1.340(2) \\ {[\mathrm{CBZ}(\mathrm{H})]\left[\mathrm{O}_{3} \mathrm{SC}_{6} \mathrm{H}_{4}(\mathrm{OH})\right]} & 1.2918(19) & 1.318(2) & 1.342(5) \\ {[\mathrm{CBZ}(\mathrm{H})]\left[\mathrm{O}_{3} \mathrm{SC}_{6} \mathrm{H}_{4}(\mathrm{OH})\right]^{\prime}} & 1.290(6) & 1.306(6) & 1.334(5) \\ {[\mathrm{CBZ}(\mathrm{H})]\left[\mathrm{O}_{3} \mathrm{SC}_{6} \mathrm{H}_{3}(\mathrm{OH})(\mathrm{COOH})\right]} & 1.285(5) & 1.322(5) & 1.336(3) \\ {[\mathrm{CBZ}(\mathrm{H})]_{2}\left[\mathrm{O}_{3} \mathrm{SCH}_{2} \mathrm{CH} \mathrm{SO}_{3}\right]} & 1.287(3) & 1.326(3) & 1.308(3) \\ \end{array}$

${ }^{a}$ Average values from 47 nondisordered, well-modeled, SXD determined molecules present in the CSD. ${ }^{28}{ }^{b}$ Range of values found for the five forms described as being solely of salt character in refs 14 and 16. 


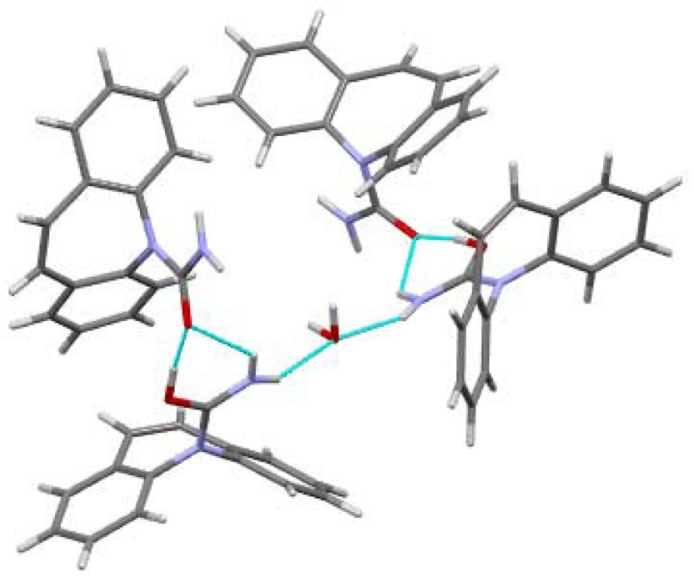

Figure 5. Two hydrogen bonded $\mathrm{CBZ} / \mathrm{CBZ}(\mathrm{H})$ dimers connected through further hydrogen bonding to a shared water molecule to give a discrete tetrameric $\left(\mathrm{CBZ}_{2} \cdot \mathrm{CBZ}(\mathrm{H})_{2} \cdot \mathrm{H}_{2} \mathrm{O}\right)$ unit.

$\mathrm{O} \cdots \mathrm{O}$ distance of $2.499(3) \AA$, the distinct $\mathrm{C}=\mathrm{O}$ and $\mathrm{C}-\mathrm{N}$ distances indicate that there is no sharing of the central $\mathrm{H}$ atom here. The $\mathrm{CBZ} / \mathrm{CBZ}(\mathrm{H})$ pair forms a $\mathrm{R} 1,2(6)$ hydrogen bonded motif that is of a type not seen before for CBZ containing species. Two of these dimers are linked through $\mathrm{N}-$ $\mathrm{H}$ to water hydrogen bonds to form discrete tetramers as shown in Figure 5. The geometry about the water molecule is completed by $\mathrm{O}-\mathrm{H}$ to $\mathrm{BF}_{4}$ hydrogen bonds. The water molecule thus has a rather typical two donor, two acceptor nature. ${ }^{29}$ However, the very "normality" of its positioning is interesting as the other structures of water containing ionic CBZ species determined by SXD either contain protonated $\mathrm{H}_{3} \mathrm{O}$ cations or, in the case of $[\mathrm{CBZ}(\mathrm{H})][\mathrm{Br}] \cdot \mathrm{H}_{2} \mathrm{O}$, a neutral water molecule that has a partial $\mathrm{H}_{3} \mathrm{O}$ character due to proton dynamics. ${ }^{14} \mathrm{CBZ} \cdot[\mathrm{CBZ}(\mathrm{H})]\left[\mathrm{BF}_{4}\right] \cdot 0.5 \mathrm{H}_{2} \mathrm{O}$ is the first hydrated $\mathrm{CBZ}(\mathrm{H})$ species to feature no amide $\mathrm{O}-\mathrm{H} \cdots$ water interaction.

Reactions of CBZ with Sulfonic Acids. Four single crystal diffraction structures were obtained for $[\mathrm{CBZ}(\mathrm{H})][\mathrm{X}]$ species where $\mathrm{X}$ is a sulfonate ion. All were obtained from reactions that involved the presence of some water, but the amount of water present varied widely. At the two extremes, $[\mathrm{CBZ}(\mathrm{H})]$ $\left[\mathrm{O}_{3} \mathrm{SC}_{6} \mathrm{H}_{4}(\mathrm{OH})\right] \cdot 0.5 \mathrm{H}_{2} \mathrm{O}$ was isolated from an entirely aqueous reaction mixture while the only water present during the formation of $[\mathrm{CBZ}(\mathrm{H})]_{2}\left[\mathrm{O}_{3} \mathrm{SCH}_{2} \mathrm{CH}_{2} \mathrm{SO}_{3}\right]$ was that introduced by using the hydrated phase of ethanedisulfonic acid. The other two species, $[\mathrm{CBZ}(\mathrm{H})]\left[\mathrm{O}_{3} \mathrm{SC}_{6} \mathrm{H}_{5}\right]$ and $[\mathrm{CBZ}(\mathrm{H})]\left[\mathrm{O}_{3} \mathrm{SC}_{6} \mathrm{H}_{3}(\mathrm{OH})(\mathrm{COOH})\right] \cdot \mathrm{H}_{2} \mathrm{O}$, were obtained by treating methanol solutions of $\mathrm{CBZ}$ with aqueous solutions of the respective sulfonic acids. In all four structures, the $\mathrm{O}$ atom of the CBZ amide group is protonated and this gives rise to the expected changes in $\mathrm{C}=\mathrm{O}$ and $\mathrm{C}-\mathrm{N}$ bond lengths, Table 2 . The two anhydrous species both form R2,2(8) hydrogen bonded heterodimers as shown in Figure 6. This is the same motif seen in the anhydrous $\mathrm{MeSO}_{3}$ salt $^{16}$ and is equivalent to the R2,2(8) hydrogen bonded heterodimers commonly described for CBZ cocrystals with carboxylic acids, ${ }^{7}$ but with the obvious difference that here the acidic proton is placed on $\mathrm{CBZ}$ rather than on the acid coformer. In the benzenesulfonate, the $\mathrm{N}-\mathrm{H}$ moiety not used in dimer formation donates a hydrogen bond to the same sulfonate $\mathrm{O}$ atom that takes part in the $\mathrm{O}-\mathrm{H} \cdots \mathrm{O}$ interaction. These interactions combine to give a one-dimensional hydrogen bonded chain that propagates parallel to the crystallographic $c$ direction; see Figure 7. The

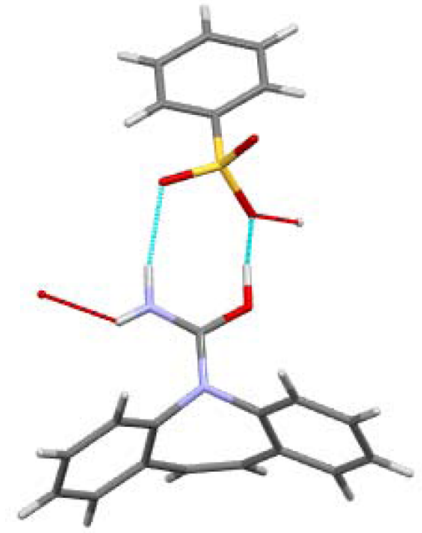

Figure 6. Heterodimer formed by hydrogen bonding between $\mathrm{CBZ}(\mathrm{H})$ cation and $\mathrm{O}_{3} \mathrm{SPh}$ anion. See Figure 7 for the expanded polymeric motif.

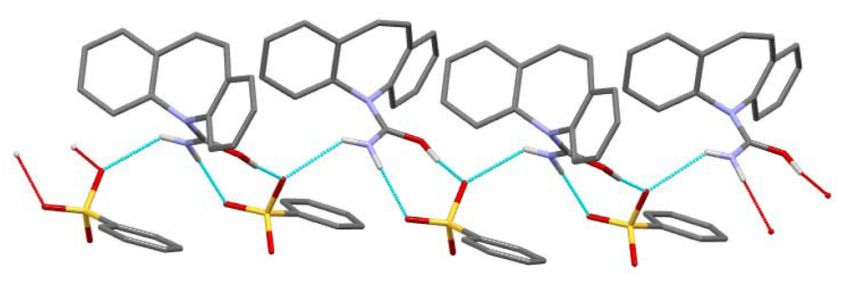

Figure 7. Cation/anion heterodimers as shown in Figure 6 connect through further $\mathrm{N}-\mathrm{H} \cdots \mathrm{O}$ hydrogen bonds to give a one-dimensional polymer. Note that one $\mathrm{O}$ atom per sulfonate group is not involved in hydrogen bonding and this results in asymmetric chains with CBZ at one side and sulfonate anions on the other.

chains pack so as to give alternate layers of cations and anions each parallel to the $b c$ plane. In the ethane disulfonate the second $\mathrm{NH}$ atom also donates a hydrogen bond to a sulfonate $\mathrm{O}$ atom, but here this forms a pair of heterodimers rather than a polymer with two R2,2(8) motifs joined by a central R2,4(8) motif; see Figure 8. In this structure the hydrogen bonded polymer relies upon the two headed nature of the anion to propagate, in this case parallel to the crystallographic $b$ direction.

Neither of the hydrated sulfonated species feature the $\mathrm{R} 2,2(8)$ hetrodimer. In $[\mathrm{CBZ}(\mathrm{H})]\left[\mathrm{O}_{3} \mathrm{SC}_{6} \mathrm{H}_{3}(\mathrm{OH})(\mathrm{COOH})\right]$. $\mathrm{H}_{2} \mathrm{O}$ a water molecule replaces one of the sulfonate $\mathrm{O}$ atoms as the acceptor of the amide $\mathrm{O}-\mathrm{H}$ hydrogen bond. This forms the three fragment R2,3(8) motif illustrated in Figure 9. The

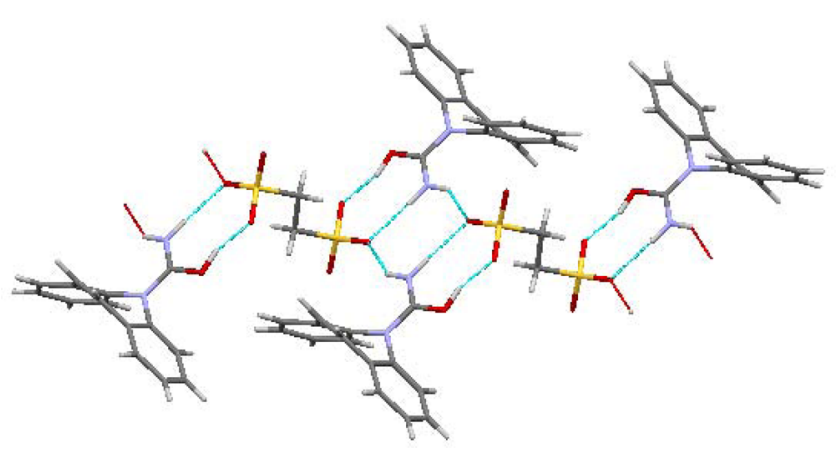

Figure 8. Hydrogen bonding in $[\mathrm{CBZ}(\mathrm{H})]_{2}\left[\mathrm{O}_{3} \mathrm{SCH}_{2} \mathrm{CH}_{2} \mathrm{SO}_{3}\right]$ illustrating the three fused hydrogen bonded rings and their connection through the two headed $\mathrm{O}_{3} \mathrm{SCH}_{2} \mathrm{CH}_{2} \mathrm{SO}_{3}$ anions. 


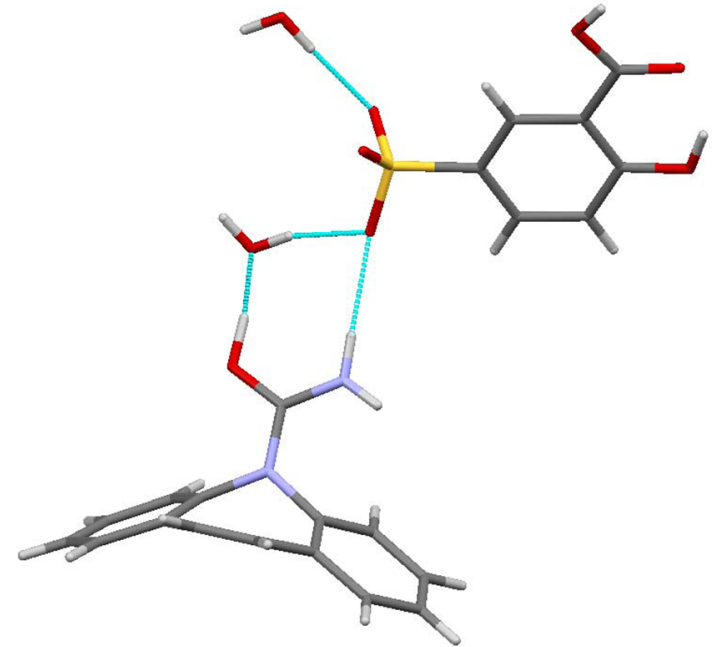

Figure 9. Cyclic hydrogen bonded motif in $[\mathrm{CBZ}(\mathrm{H})]$ $\left[\mathrm{O}_{3} \mathrm{SC}_{6} \mathrm{H}_{3}(\mathrm{OH})(\mathrm{COOH})\right] \cdot \mathrm{H}_{2} \mathrm{O}$ with a water molecule substituted into the R2,2(8) heterodimer pair seen in Figure 6.

similar motif involving both water and anion is formed by one of the two crystallographically independent $\mathrm{CBZ}(\mathrm{H})$ ions of $[\mathrm{CBZ}(\mathrm{H})]\left[\mathrm{O}_{3} \mathrm{SC}_{6} \mathrm{H}_{4}(\mathrm{OH})\right] \cdot 0.5 \mathrm{H}_{2} \mathrm{O}$ although here two $\mathrm{O}$ atoms of the sulfate group are involved rather than one, giving a $\mathrm{R} 3,3(10)$ motif. The second independent $\mathrm{CBZ}(\mathrm{H})$ ion does form a heterodimer with the sulfonate anion but bonds to only one of the sulfonate group's $\mathrm{O}$ atoms to give a $\mathrm{R} 1,2(6)$ motif.

\section{CONCLUSIONS}

Despite earlier reports that protonation of $\mathrm{CBZ}$ requires nonaqueous media, we find that this is not true. Indeed, far from giving only $\mathrm{CBZ}$ dihydrate, reaction of $\mathrm{CBZ}$ with strong acids in strictly aqueous media is found to give a variety of product types, namely, anhydrous salt forms $([\mathrm{CBZ}(\mathrm{H})][\mathrm{X}], \mathrm{X}$ $=\mathrm{Cl}$ or $\mathrm{Br})$, hydrated salts $\left([\mathrm{CBZ}(\mathrm{H})][\mathrm{X}] \cdot n \mathrm{H}_{2} \mathrm{O}, \mathrm{X}=\mathrm{Cl}, \mathrm{Br}\right.$, $\left.\mathrm{O}_{3} \mathrm{SC}_{6} \mathrm{H}_{4}(\mathrm{OH})\right)$, mixed $\mathrm{CBZ} / \mathrm{CBZ}(\mathrm{H})$ salts $(\mathrm{CBZ} \cdot[\mathrm{CBZ}(\mathrm{H})]-$ $\left.\left[\mathrm{BF}_{4}\right]\right)$, and ICC forms containing hydronium $\left([\mathrm{CBZ}]_{2}\left[\mathrm{H}_{3} \mathrm{O}\right]\right.$ $[\mathrm{Cl}], \mathrm{CBZ} \cdot\left[\mathrm{H}_{5} \mathrm{O}_{2}\right]_{0.25}\left[\mathrm{BF}_{4}\right]_{0.25}$ ) or acridinium cations (CBZ. $\left.\left[\mathrm{C}_{13} \mathrm{H}_{10} \mathrm{~N}\right]\left[\mathrm{I}_{3}\right] \cdot 2.5 \mathrm{I}_{2}\right)$. Mixed alcohol/water solvent systems were adopted to improve solubility and hence crystal growth properties, and these conditions were also found to allow access to salt forms of CBZ with both mineral acids and sulfonic acids. In total this approach has increased the number of structurally characterized $\mathrm{CBZ}(\mathrm{H})$ salt forms from seven to 13 and allows access to two new ICC forms of CBZ. Neutral CBZ and cationic $\mathrm{CBZ}(\mathrm{H})$ species have been shown to have distinctly different $\mathrm{C}=\mathrm{O}$ and $\mathrm{C}-\mathrm{N}$ amide bond lengths from each other, to such an extent that intermediate bond lengths can be taken to indicate the presence of a dynamic equilibrium between CBZ and $\mathrm{CBZ}(\mathrm{H})$ moieties. $^{14,16} \mathrm{CBZ}(\mathrm{H})$ cations also differ from CBZ molecules in the nature of their hydrogen bonding. Neither of the common homo-CBZ supramolecular structures (dimer or chain) is observed for $\mathrm{CBZ}(\mathrm{H})$ species, but a close relative of the heterodimer observed for $\mathrm{CBZ} /$ carboxylic acid cocrystals is seen in the $\mathrm{R} 2,2(8)$ dimers formed here between $\mathrm{CBZ}(\mathrm{H})$ cations and sulfonate anions. This structural motif is absent from hydrated crystals of sulfonate salts of $\mathrm{CBZ}(\mathrm{H})$.

\section{ASSOCIATED CONTENT}

\section{Supporting Information}

The Supporting Information is available free of charge on the ACS Publications website at DOI: 10.1021/acs.cgd.5b01223.

Details of the Pawley and Rietveld fits of the PXRD data measured for the powders isolated from reactions of $\mathrm{CBZ}$ with concentrated aqueous $\mathrm{HCl}$ and $\mathrm{HBr}$ (PDF) Files for all new structures discussed (CIF)

\section{AUTHOR INFORMATION}

\section{Corresponding Author}

*E-mail: a.r.kennedy@strath.ac.uk.

\section{Notes}

The authors declare no competing financial interest.

\section{REFERENCES}

(1) Arlin, J.-B.; Price, L. S.; Price, S. L.; Florence, A. J. Chem. Commun. 2011, 47, 7074.

(2) Lang, M.; Kampf, J. W.; Matzger, A. J. J. Pharm. Sci. 2002, 91, 1186.

(3) Grzesiak, A. L.; Lang, M.; Kim, K.; Matzger, A. J. J. Pharm. Sci. 2003, 92, 2260.

(4) Childs, S. L.; Wood, P. A.; Rodriguez-Hornedo, N.; Reddy, L. S.; Hardcastle, K. I. Cryst. Growth Des. 2009, 9, 1869.

(5) Majumder, M.; Buckton, G.; Rawlinson-Malone, C.; Williams, A. C.; Spillman, M. J.; Shankland, N.; Shankland, K. CrystEngComm 2011, 13, 6327.

(6) Childs, S. L.; Rodriguez-Hornedo, N.; Reddy, L. S.; Jayasankar, A.; Maheshwari, C.; McCausland, L.; Shipplett, R.; Stahly, B. C. CrystEngComm 2008, 10, 856.

(7) Fleischman, S. G.; Kuduva, S. S.; McMahon, J. A.; Moulton, B.; Walsh, R. D. B.; Rodriguez-Hornedo, N.; Zaworotko, M. J. Cryst. Growth Des. 2003, 3, 909.

(8) Horstman, E. M.; Goyal, S.; Pawate, A.; Lee, G.; Zhang, G. G. Z.; Gong, Y. C.; Kenis, P. J. A. Cryst. Growth Des. 2015, 15, 1201.

(9) Qiu, S.; Li, M. Z. Int. J. Pharm. 2015, 479, 118.

(10) Patil, S. P.; Modi, S. R.; Bansal, A. K. Eur. J. Pharm. Sci. 2014, 62, 251.

(11) Kudo, S.; Takiyama, T. J. Cryst. Growth 2014, 392, 87.

(12) Reck, G.; Thiel, W. Pharmazie 1991, 46, 509.

(13) Buist, A. R.; Kennedy, A. R. Cryst. Growth Des. 2014, 14, 6508.

(14) Buist, A. R.; Kennedy, A. R.; Shankland, K.; Shankland, N.; Spillman, M. J. Cryst. Growth Des. 2013, 13, 5121.

(15) Perumalla, S. R.; Sun, C. C. Chem. - Eur. J. 2012, 18, 6462.

(16) Eberlin, A. R.; Eddleston, M. D.; Frampton, C. S. Acta Crystallogr., Sect. C: Cryst. Struct. Commun. 2013, C69, 1260.

(17) Gelbrich, T.; Hursthouse, M. B. CrystEngComm 2006, 8, 448.

(18) Perumalla, S. R.; Shi, L.; Sun, C. C. CrystEngComm 2012, 14, 2389.

(19) Braga, D.; Grepioni, F.; Maini, L.; Capucci, D.; Nanna, S.; Wouters, J.; Aerts, L.; Quéré, L. Chem. Commun. 2012, 48, 8219.

(20) Bethune, S. J.; Huang, N.; Jayasankar, A.; Rodriguez-Hornedo, N. Cryst. Growth Des. 2009, 9, 3976.

(21) Huang, N.; Rodriguez-Hornedo, N. Cryst. Growth Des. 2010, 10, 2050.

(22) Nanubolu, J. B.; Sridhar, B.; Ravikumar, K. CrystEngComm 2012, 14, 2571.

(23) Sheldrick, G. M. Acta Crystallogr., Sect. A: Found. Crystallogr. 2008, 64, 112.

(24) Coelho, A. A. TOPAS User Manual; Bruker AXS GmbH: Karlsruhe, Germany, 2003.

(25) Csetenyi, J.; Baker, K. M.; Frigerio, A.; Morselli, P. L. J. Pharm. Pharmacol. 1973, 25, 340.

(26) Furst, S. M.; Uetrecht, J. P. Biochem. Pharmacol. 1993, 45, 1267.

(27) Jelic, A.; Cruz-Morató, C.; Marco-Urrea, E.; Sarrá, M.; Perez, S.; Vicent, T.; Petrović, M.; Barcelo, D. Water Res. 2012, 46, 955. 
(28) Allen, F. H. Acta Crystallogr., Sect. B: Struct. Sci. 2002, 58, 380.

(29) Gillon, A. L.; Feeder, N.; Davey, R. J.; Storey, R. Cryst. Growth Des. 2003, 3, 663. 